\title{
Pengembangan Game Edukasi Pengenalan Angka Berbasis Unity Untuk Anak Berkebutuhan Khusus (ABK) Tunagrahita Di SLB Arnadya
}

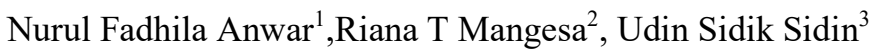 \\ Pendidikan Teknik Informatika dan Komputer, Universitas Negeri Makassar \\ ${ }^{1}$ nurulfadhilaanwar98@gmail.com \\ ${ }^{2}$ Rianamangesa@yahoo.com
}

\begin{abstract}
Abstrak- Penilitian ini bertujuan untuk mengembangkan Game Edukasi Pengenalan Angka berbasis Unity untuk Anak Berkebutuhan Khusus (ABK) Tunagrahita di SLB Arnadya yang berdasarkan standar ISO 25010. Penelitian ini termasuk jenis penelitian Research and Development $(R \& D)$ Software Development. Penelitian ini menggunakan model pengembangan ADDIE. Teknik pengumpulan datanya menggunakan teknik instrumen atau angket. Pengujian sistem ini menggunakan standar ISO 25010 yang berfokus pada pengujian functionality suitability, usability, performance efficiency, portability dan compability. Adapun hasil pengujian pada functional suitability yang diuji oleh ahli sistem dengan mengisi kuesioner yang berisi 33 pertanyaan terkait fungsi-fungsi yang didesain dalam sistem yang dikembangkan. Dari pengujian tersebut, diperoleh hasil yang berada pada kategori sangat baik; pada pengujian portability\&compability dilakukan uji coba pada 6 perangkat yang berbeda dan diperoleh nilai berhasil dari semua perangkat pengujian; pengujian aspek performance efficiency dilakukan dengan menggunakan Profile tools dari Unity hasil dari penggunaan CPU dan memori efisien sehingga berada pada kategori baik; pada pengujian aspek usability yang dilakukan pada 10 orang responden dengan mengajukan sebanyak 30 pertanyaan diperoleh nilai rata-rata persentase $89 \%$ dengan kategori sangat baik.
\end{abstract}

Kata Kunci : Game Edukasi, Pengenalan Angka, Unity, Tunagrahita, ISO 25010.

\section{PENDAHULUAN}

Pendidikan merupakan salah satu hal yang penting bagi anak - anak di dalam menjalani kehidupan sehari - hari. Melalui pendidikan anak- anak dapat memperoleh ilmu pengetahuan yang bermanfaat untuk diri sendiri, keluarga, serta masyarakat. Pentingnya pendidikan juga dicantumkan dalam Undang - undang dasar 1945 pasal 31 ayat 1 yang menjelaskan bahwa setiap warga Negara berhak untuk mendapatkan pendidikan. Sehingga semua warga Negara termasuk Anak Berkebutuhan Khusus (ABK) juga berhak untuk memperoleh pendidikan.

Dalam dunia pendidikan Luar Biasa terdapat beberapa Anak Berkebutuhan Khusus (ABK), salah satunya adalah anak penyandang tunagrahita. Anak berkebutuhan khusus adalah anak yang memiliki karakteristik khusus dibandingkan dengan anak pada umumnya. Salah satu jenis anak berkebutuhan khusus adalah anak dengan keterbatasan intelektual atau sering disebut anak tunagrahita. Menurut Mulyadi (2012), anak tunagrahita memiliki tingkat intelektual di bawah rata- rata, yaitu IQ di bawah 70 . Perhatian dan ingatan anak tunagrahita lemah, tidak dapat memperhatikan sesuatu hal dengan serius dan lama, sebentar saja perhatian anak tunagrahita akan berpindah pada persoalan lain, apalagi dalam hal memperhatikan pelajaran, anak tunagrahita cepat merasa bosan.

Kemampuan intelektual anak tunagrahita yang berada di bawah rata-rata ini mengakibatkan mereka mengalami kesulitan dalam menerima pelajaran, salah satunya pelajaran Matematika. Dalam kurikulum Sekolah Dasar Luar Biasa Tunagrahita (SDLBC), salah satu materi pembelajaran matematika yang wajib diberikan pada peserta didik tunagrahita yaitu pengenalan angka. Pemahaman dalam pengenalan angka bagi anak tunagrahita sangat penting, karena pengenalan angka adalah konsep awal untuk pelajaran Matematika. Dengan pemahaman pengenalan angka ini, anak tunagrahita akan lebih mudah dalam menerima pelajaran berhitung.

Game edukasi merupakan suatu media yang memungkinkan pengguna game tersebut dapat bermain sekaligus belajar sehingga tanpa disadari akan menambah minat belajar bagi pengguna game tersebut. Mata pelajaran matematika khususnya berhitung merupakan materi akademik yang sangat penting karena diajarkan pada setiap jenjang pendidikan.

Berdasarkan hasil pra-penelitian di SLB Arnadya yang dilaksanakan pada hari Selasa tanggal 30 Juni 2020 dengan melakukan wawancara dengan salah satu guru kelas tunagrahita kelas II diketahui bahwa dalam proses pembelajaran untuk peserta didik tunagrahita selama ini belum menggunakan media pembelajaran dengan memanfaatkan teknologi atau masih berbentuk media cetak dan alat peraga. Peserta didik kategori Tunagrahita digabung dalam kelas berdasarkan kualifikasi tunagrahita ringan, sedang dan berat. Lebih lanjut, media dan sumber belajar kurang bervariasi yaitu penggunaan media lain seperti komputer masih belum digunakan. Pembagian kelas Tunagrahita di SLB Arnadya terdiri dari 4 kelas dengan masingmasing dipegang oleh satu guru.

Hasil observasi awal menunjukkan bahwa mata pelajaran Matematika di kelas Tunagrahita khususnya dalam materi pengenalan angka berbeda-beda. Pada kelas Tunagrahita klasifikasi berat, materi pengenalan angka mampu mengenal simbol bilangan 1-20. Namun, beberapa peserta didik tunagrahita masih mengalami beberapa hambatan seperti belum mampu mengenal dan menyebutkan bilangan sehingga masih membutuhkan bimbingan dan pengawasan oleh guru dalam menerima materi. Adapun di kelas Tunagrahita klasifikasi ringan, sudah mampu mengenal simbol bilangan 1-60.

Hasil observasi awal juga menunjukkan bahwa media yang digunakan belum bervariasi. Padahal media pembelajaran merupakan salah satu penunjang untuk mencapai keberhasilan pembelajaran. Beberapa anak tunagrahita di SLB Arnadya mampu menggunakan smartphone dalam hal ini, bermain game. Anak tunagrahita mampu menyimpan dan mengandalkan beberapa memori atau ingatan dengan melihat instruksi yang diarahkan, sehingga mampu dalam bermain game pada smartphone. Melihat kondisi ini, perlu dikembangkannya media pembelajaran Matematika yang sesuai dengan kebutuhan peserta didik tunagrahita berupa software berbasis game seperti aplikasi permainan edukasi yaitu aplikasi permainan yang bukan hanya memberi hiburan kepada peserta didik tunagrahita tetapi juga sebagai media dalam proses pembelajaran yang dapat 
memudahkan peserta didik tunagrahita dalam memahami materi Pengenalan Angka yang selama ini mengandalkan ingatannya untuk menghafal simbol-simbol bilangan sehingga aplikasi game tersebut dapat menimbulkan rasa senang selama proses pembelajaran berlangsung.

Berdasarkan uraian di atas, maka penulis tertarik untuk meneliti "Pengembangan Game Edukasi Pengenalan Angka berbasis Unity untuk Anak Berkebutuhan Khusus (ABK) Tunagrahita di SLB Arnadya". Game ini diharapkan dapat membuat suasana kelas menjadi menyenangkan dan menarik bagi anak tunagrahita, sehingga anak tidak bosan dan dapat menerima pelajaran dengan mudah.

\section{METODE PENELITIAN}

\section{Jenis Penelitian}

Penelitian ini menggunakan jenis penelitian Research and Development, atau yang biasa dikenal dengan (R\&D). Metode penelitian ini tidak bertujuan untuk menemukan/membuat teori, melainkan penelitian ini bertujuan untuk membuat sebuah produk tertentu. Menurut Sugiyono (2010) Research And Development adalah metode penelitian yang digunakan untuk menghasilkan produk tertentu dan menguji keefektifan produk tersebut.

Dalam hal ini, peneliti mengembangkan sebuah produk pembelajaran berupa Game Edukasi Pengenalan Angka menggunakan Unity untuk Anak Berkebutuhan Khusus Tunagrahita. Model pengembangan perangkat lunak yang digunakan adalah Model ADDIE.

\section{Tempat dan Waktu Penelitian}

Penelitian ini dilaksanakan di SLB Arnadya, Jalan Tamangapa Raya 3 No.45, Kelurahan Bangkala, Kota Makassar. Penelitian dilaksanakan pada tahun ajaran 2020/2021 semester 1.

\section{Subjek Uji Coba \\ Uji Coba Kelompok Kecil}

Uji coba kelompok kecil ini dilakukan pada satu sampai dua orang peserta didik golongan Tunagrahita. Uji coba ini dilakukan untuk mengetahui kekurangan yang dimiliki oleh game edukasi berdasarkan penilaian peserta didik sehingga dapat dilakukan revisi.

\section{Uji Coba Kelompok Kecil}

Uji coba kelompok besar merupakan uji coba yang dilakukan pada 10 peserta didik Tunagrahita. Uji coba ini dilakukan untuk mengetahui kekurangan yang masih terdapat pada game edukasi setelah dilakukan revisi produk setelah uji coba kelompok kecil. Setelah revisi pada tahap ini dilakukan maka dapat diketahui kelayakan pada produk akhir game edukasi pengenalan angka.

\section{Prosedur Penelitian dan Pengembangan}

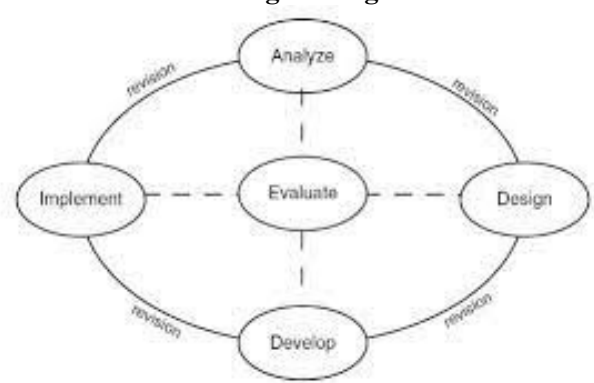

Gambar 1. Prosedur Penelitian dan Pengembangan

Pengembangan game edukasi pengenalan angka di SLB Arnadya pada penelitian ini mengacu pada model pengembangan ADDIE yang terdiri dari lima tahap, yaitu analisis (analyze), desain (design), pengembangan (development), implementasi (implementation) dan evaluasi (evaluation). Model pengembangan ADDIE dipilih berdasarkan kelebihannya, yaitu: (1) dapat digunakan sebagai dasar untuk mengembangkan media pembelajaran karena bersifat umum, (2) uraian pada model ini lebih lengkap dan sistematis, sehingga memudahkan peneliti mengontrol pelaksanaannya, (3) dalam pengembangannya melibatkan penilaian ahli, sehingga sebelum dilakukan uji coba di lapangan perangkat pembelajaran telah dilakukan revisi berdasarkan penilaian, saran dan masukan para ahli, (4) sederhana, terstruktur, dan sistematis.

\section{Teknik Pengumpulan Data}

Metode pengumpulan data yang digunakan dalam penelitian ini yaitu menggunakan wawancara, penyebaran Kuisioner (angket) dan Observasi untuk melihat hasil pengembangan media pembelajaran pada peserta didik.

\section{Wawancara}

Wawancara yang dilakukan guna melihat data awal pada penelitian yang nantinya dipakai sebagai masukan dalam mengembangkan Game Edukasi menggunakan unity yang dikembangkan untuk media pembelajaran.

\section{Observasi}

Metode observasi dalam penelitian ini digunakan untuk mengamati proses pembelajaran siswa dengan menggunakan bantuan media pembelajaran. Observasi atau dengan pengamatan langsung adalah cara pengambilan data dengan menggunakan mata tanpa ada pertolongan alat standar lain untuk keperluan tersebut.

3. Tes

Pada pengumpulan data dengan metode angket atau kuisioner, terlebih dahulu peneliti menyusun kisi-kisi instrumen angket atau kuisioner yang akan diberikan kepada responden. Pada angket tersebut masing-masing terdiri dari 15 soal tiap angket.

Tabel 1. Kisi-Kisi Instrumen Validator Materi

\begin{tabular}{|c|c|c|c|c|}
\hline \multicolumn{5}{|c|}{ Kisi-Kisi Instrumen Validator Materi } \\
\hline No & Aspek & Indikator & No Soal & Jumlah \\
\hline \multirow[t]{4}{*}{1.} & \multirow{4}{*}{$\begin{array}{l}\text { Tampilan } \\
\text { Media }\end{array}$} & Komposisi layout & 1 & 1 \\
\hline & & Komposisi warna & 2 & 1 \\
\hline & & Ukuran dan bentuk huruf & 3,4 & 2 \\
\hline & & Kesesuaian animasi & 5 & 1 \\
\hline \multirow[t]{4}{*}{2.} & \multirow[t]{4}{*}{ Pembelajaran } & $\begin{array}{l}\text { Kesesuaian materi dengan } \\
\text { kurikulum pendidikan }\end{array}$ & 6,7 & 2 \\
\hline & & Kejelasan petunjuk penggunaan & 8 & 1 \\
\hline & & Ketepatan program & 9 & 1 \\
\hline & & Variasi materi & 10 & 1 \\
\hline \multirow[t]{5}{*}{3.} & \multirow[t]{5}{*}{ Isi } & Kejelasan Materi & 11 & 1 \\
\hline & & Penyusunan materi & 12 & 1 \\
\hline & & Contoh soal & 13 & 1 \\
\hline & & Kesesuaian penggunaan bahasa & 14 & 1 \\
\hline & & Kejelasan informasi & 15 & 1 \\
\hline \multicolumn{4}{|c|}{ Jumlah } & 15 \\
\hline
\end{tabular}

\section{Teknik Analisis Data}

Teknik analisis data yang digunakan untuk mengolah data hasil penelitian pengembangan game edukasi pengenalan angka yaitu dengan menggunakan analisis statistik deskriptif yang meliputi :

\section{Analisis Data Kualitatif}

Data ini diperoleh dari ahli materi, ahli media, dan peserta didk berupa koreksi dan masukan. Koreksi dan masukan tersebut digunakan sebagai acuan revisi produk. 


\section{Analisis Data Kuantitatif}

Penilaian kelayakan media pembelajaran oleh ahli media dan ahli materi. Data penilaian produk diperoleh dari hasil isian angket oleh ahli media, ahli materi, dan peserta didik.

\section{HASIL DAN PEMBAHASAN}

\section{Hasil Tahap Design}

Tahap desain merupakan tahapan perancangan game edukasi yang meliputi rumusan tujuan pembuatan game edukasi pengenalan angka sesuai dengan kebutuhan peserta didik, pembuatan flowchart untuk alur media pembelajaran, pembuatan storyboard dan desain antarmuka sebagai rancangan awal pembuatan media pembelajaran game edukasi, pengumpulan objek rancangan sesuai dengan materi terdapat pada media pembelajaran, dan penyusunan instrumen untuk menguji kelayakan media game edukasi sebagai sumber belajar peserta didik.

\section{a. Uji Pengumpulan Objek Rancangan}

1) Mengumpulkan materi serta contoh pembuatan game edukasi. Materi disusun sesuai dengan referensi yang ada serta dibuat secara runtut untuk memudahkan peserta didik dalam mempelajari materi.

2) Pengumpulan gambar, audio, tombol, dan lain-lain.Gambar di desain menggunakan software CorelDraw dan beberapa diunduh dari berbagai sumber yang kemudian dimasukkan (dimport) ke dalam media pembelajaran untuk pendukung suatu materi. Audio berupa instrumental yang menarik untuk didengar siswa dalam belajar menggunakan media pembelajaran game edukasi serta pengisi suara direkam menggunakan suara peneliti menggunakan aplikasi Voice changer kemudian di edit menggunakan software Lexis Audio Editor. Tombol dibuat sesuai dengan estetika dan etika multimedia. Semua objek diproses dengan menggunakan unity untuk dijadikan media pembelajaran game edukasi. Teks/font, background, dan musik latar didapat dengan cara mengunduh dari penyedia 2D assets game gratis yang ada diinternet, diantaranya: dafont.com, freepik.com, dan Unity store.

\section{b. Penyusunan Instrumen Uji Kelayakan}

Instrumen dibuat dalam bentuk angket yang disajikan kepada ahli media, ahli materi dan responden menggunakan tipe jawaban berupa check list $(\sqrt{ })$. Hasil Penilaian Materi dari media pembelajaran game edukasi divalidasi oleh Mustamin, S.Pd., M.Pd., M.T (Dosen Jurusan Pendidikan Teknik Elektro) dengan penilaian "Layak untuk Uji Coba Lapangan dengan Revisi" dan Drs. H. Alimuddin Sa'ban Miru, M.Pd. (Dosen Jurusan Pendidikan Teknik Elektro) dengan penilaian "Layak untuk Uji Coba Lapangan", sedangkan hasil penilaian media divalidasi oleh Dr. Satria Gunawan Zain, S.Pd., M.T (Dosen Prodi Teknik Komputer) dan Abdul Rahman Patta, S.Kom., M.T. (Dosen Prodi Teknik Komputer) dengan penilaian "Layak untuk Uji Coba Lapangan dengan Revisi".

\section{Hasil Tahap Develop}

\section{a. Pembuatan Media Pembelajaran Game Edukasi}

Tahapan pembuatan media yaitu dengan merangkai semua komponen seperti materi, evaluasi, gambar, dan music sehingga menjadi Media Pembelajaran Game Edukasi menggunakan software unity. Desain media pembelajaran game edukasi sesuai dengan flowchart dan storyboard yang telah dirancang sebelumnya. Hasil pembuatan game edukasi dari unity yang kemudian akan di eksport atau build menjadi aplikasi berupa file extension (*.apk) yang gunanya untuk memudahkan dalam menjalankan media pembelajaran game edukasi pada Android. b. Desain Antarmuka

1) Halaman Splash

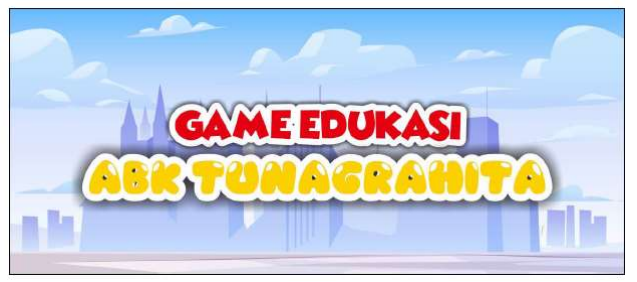

Gambar 2. Antarmuka Halaman Spash

2) Halaman Menu Utama

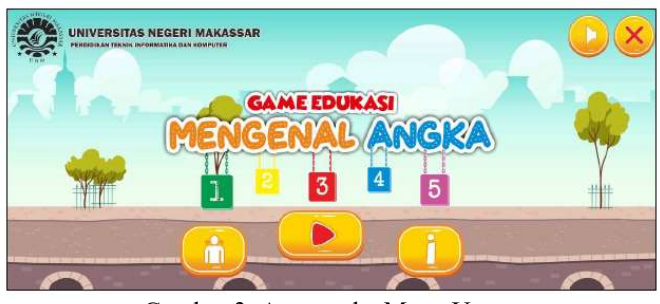

Gambar 3. Antarmuka Menu Utama

3) Halaman Menu Pembelajaran

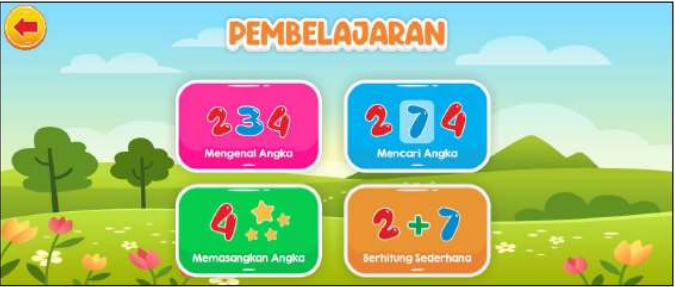

Gambar 4. Antarmuka Halaman Menu Pembelajaran

4) Halaman Menu Mengenal Angka

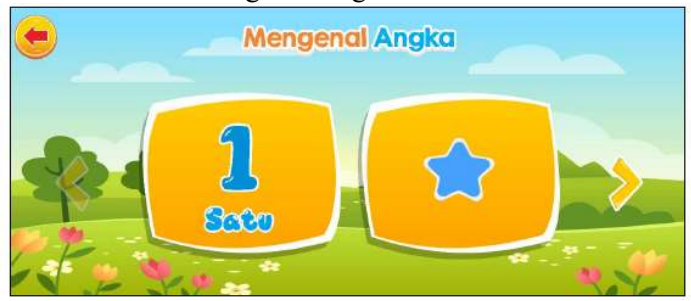

Gambar 5. Antarmuka Halaman Menu Mengenal Angka

5) Halaman Menu Mencari Angka

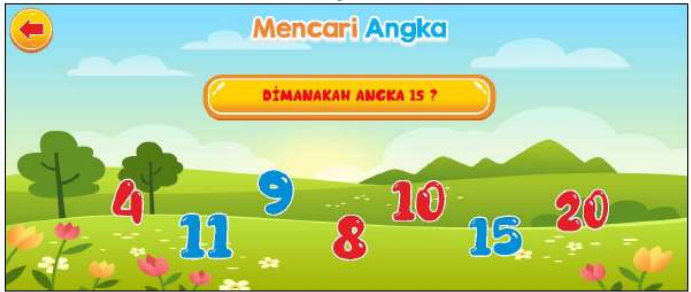

Gambar 6. Antarmuka Halaman Menu Mencari Angka

6) Halaman Menu Memasangkan Angka

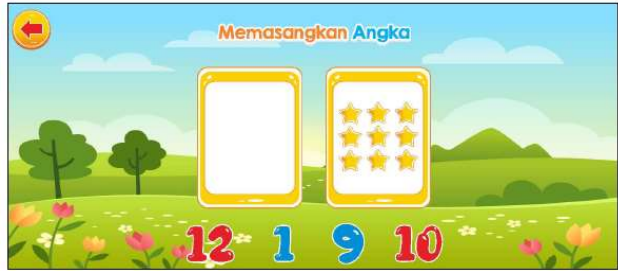

Gambar 7. Antarmuka Halaman Menu Memasangkan Angka 
7) Halaman Menu Berhitumg Sederhana

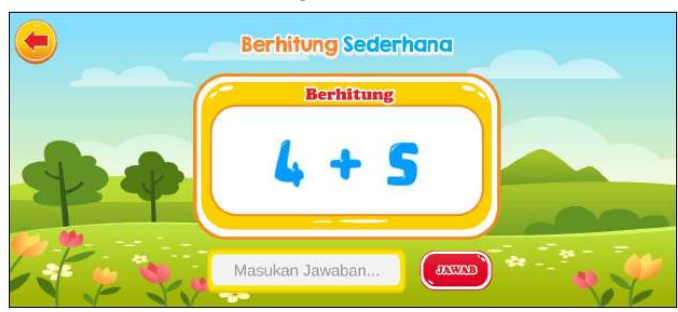

Gambar 8. Antarmuka Halaman Menu Berhitung Sederhana

3. Hasil Tahap Implementasi

a. Uji Coba Kelompok Kecil

Tahap uji coba kelompok kecil dilakukan pada dua peserta didik golongan Tunagrahita dengan karakteristik paling lemah dalam kemampuan berhitungnya di SLB Arnadya pada tanggal 10 Desember 2020, pukul 09.00 di kelas II Tunagrahita. Peneliti menyediakan dua buah smartphone yang digunakan peserta didik dalam tahap uji coba kelompok kecil. Pada tahap ini peserta didik diberi kesempatan untuk mengoperasikan game edukasi sambil peneliti mengamati dan mengisi kuesioner yang telah disediakan.

Penilaian terhadap game edukasi pada saat uji coba kelompok kecil menunjukkan hampir semua item penilaian diberi nilai "cukup baik". Peserta didik juga masih diberi arahan oleh guru ketika mengoperasikan game edukasi . Uji coba kelompok kecil dilakukan sebagai bahan untuk melakukan perbaikan atau saran dan komentar yang diberikan terhadap game edukasi pengenalan angka. Saran dan masukan dari guru yaitu instruksi atau informasi ditambahkan dalam game edukasi yang dapat didengar dengan jelas oleh peserta didik.

\section{b. Uji Coba Kelompok Besar}

Tahap uji coba kelompok besar dilakukan pada 10 peserta didik golongan Tunagrahita dengan karakteristik paling lemah dalam kemampuan berhitungnya di SLB Arnadya pada tanggal 14 Desember 2020, pukul 08.30 di kelas Tunagrahita. Peneliti menyediakan lima buah smartphone yang digunakan peserta didik dalam tahap uji coba kelompok besar. Pada tahap ini peserta didik diberi kesempatan untuk mengoperasikan game edukasi sementara guru dan orangtua/wali peserta didik mengamati dan mengisi kuesioner yang telah disediakan.

Hasil penilaian game edukasi yang dilakukan oleh 10 peserta didik pada uji coba lapangan menunjukkan bahwa game edukasi termasuk kedalam kategori "sangat baik". Pada tahap uji coba lapangan ini dari hasil pengamatan memberikan komentar bahwa game edukasi ini mudah untuk dioperasikan dan menarik sehingga membuat peserta tidak cepat merasa bosan saat belajar.

c. Pengujian Game Edukasi Pengenalan Angka berdasarkan standar ISO 25010

1) Pengujian Aspek Functionality suitability pada Game Edukasi Pengenlan Angka

Tabel 2. Rekapitulasi Pengujian Funcionalty

\begin{tabular}{|l|l|l|l|l|l|l|}
\multirow{2}{*}{ Jawaban } & \multicolumn{2}{|c|}{ Skor oleh validator } & $\begin{array}{c}\text { Skor } \\
\text { maks }\end{array}$ & $\begin{array}{c}\text { Total } \\
\text { Skor }\end{array}$ & X & Kategori \\
\cline { 2 - 6 } & validator 1 & validator 2 & & & \\
\hline Ya & 33 & 33 & 66 & 66 & 1 & Baik \\
\hline Tidak & 0 & 0 & 0 & 0 & - & \\
\hline
\end{tabular}

Dari pengujian didapatkan hasil pengujian dengan nilai $\mathrm{X}=1$, Hal ini berarti bahwa aspek functionality suitability media pembelajaran game edukasi pengenlan angka yang dikembangkan berada pada kategori "Layak".
3) Pengujian Aspek Performance Efficiency pada Game Edukasi Pengenlan Angka

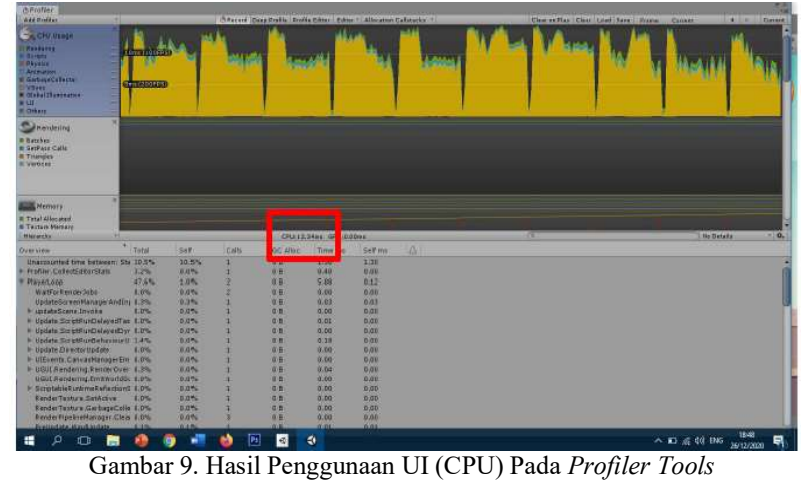

Pada grafik pengujian performance efficiency diperoleh pada UI (CPU) max 12,34 ms/frame, dari perolehan avg (rata-rata) dibawah $16 \mathrm{~ms} /$ frame yang merupakan tolak ukur standar pengujian Profiler tools dari Unity, karena jika semakin tinggi fps yang dihasilkan, maka gerakan yang terasa di dalam game akan semakin halus dan lancar, sehingga dapat dikategorikan "sangat baik" dan telah memenuhi aspek pengujian performance efficiency.

3) Pengujian Aspek Portability \& Compability pada Game

Edukasi Pengenalan Angka

Tabel 3. Rekapitulasi Penilaian Pada Aspek Portaibility

\begin{tabular}{|c|l|c|c|}
\hline No & \multicolumn{1}{|c|}{ Aplikasi yang dijalankan } & Berhasil & Gagal \\
\hline 1. & Samsung Galaxy Grand Neo Plus & 1 & 0 \\
\hline 2. & OPPO A37 & 1 & 0 \\
\hline 3. & XIAOMI REDMI 5PLUS & 1 & 0 \\
\hline 4. & OPPO A7 & 1 & 0 \\
\hline 5. & Vivo Y2 & 1 & 0 \\
\hline 6. & OPPO A92 & 1 & 0 \\
\hline \multicolumn{2}{c|}{ Total } & 6 & 0 \\
\hline \multicolumn{2}{c|}{ Kategori } & 1 & - \\
\hline \multicolumn{2}{c|}{ Baik } \\
\hline
\end{tabular}

Tabel 4. Rekapitulasi Penilaian Pada Aspek Compatibility

\begin{tabular}{|c|c|c|c|}
\hline No. & Aplikasi yang dijalankan & Berhasil & Gagal \\
\hline 1. & $\begin{array}{c}\text { Game Edukasi Pengenalan Angka dan } \\
\text { Whatsapp }\end{array}$ & 1 & 0 \\
\hline 2. & $\begin{array}{c}\text { Game Edukasi Pengenalan Angka dan } \\
\text { Youtube }\end{array}$ & 1 & 0 \\
\hline $\mathbf{3 .}$ & $\begin{array}{c}\text { Game Edukasi Pengenalan Angka dan } \\
\text { Google Chrome }\end{array}$ & 1 & 0 \\
\hline $\mathbf{4 .}$ & $\begin{array}{c}\text { Game Edukasi Pengenalan Angka dan } \\
\text { Gojek }\end{array}$ & 1 & 0 \\
\hline $\mathbf{5 .}$ & $\begin{array}{c}\text { Game Edukasi Pengenalan Angka dan } \\
\text { WPS Office }\end{array}$ & 1 & 0 \\
\hline $\mathbf{6 .}$ & $\begin{array}{c}\text { Game Edukasi Pengenalan Angka dan } \\
\text { Telegram }\end{array}$ & 1 & 0 \\
\hline & $\begin{array}{c}\text { Total } \\
\mathbf{X}\end{array}$ & 6 & 0 \\
\hline \multicolumn{3}{|c|}{ Baik } \\
\hline
\end{tabular}

Dapat disimpulkan bahwa persentase kesuksesan pengujian aspek portability \& compability didapatkan hasil pengujian dengan nilai $X=1$, sehingga dapat dikatakan bahwa game pengenalan angka sudah memenuhi aspek portability \& compability. 


\section{4) Pengujian Aspek Usability pada Game Edukasi Pengenalan Angka}

\begin{tabular}{|c|c|c|c|}
\multicolumn{5}{|c}{ Tabel 5. Rekapitulasi Hasil Pengujian Aspek Usability } \\
\hline $\begin{array}{c}\text { No. } \\
\text { Responden }\end{array}$ & Skor Perolehan & Skor Maksimal & $\begin{array}{c}\text { Persentase Usability } \\
(\%)\end{array}$ \\
\hline 1. & 114 & 150 & $76 \%$ \\
\hline 2. & 112 & 150 & $74 \%$ \\
\hline 3. & 144 & 150 & $96 \%$ \\
\hline 4. & 139 & 150 & $92 \%$ \\
\hline 5. & 128 & 150 & $85 \%$ \\
\hline 6. & 147 & 150 & $98 \%$ \\
\hline 7. & 145 & 150 & $96 \%$ \\
\hline 8. & 138 & 150 & $92 \%$ \\
\hline 9. & 130 & 150 & $86 \%$ \\
\hline 10. & 144 & 150 & $96 \%$ \\
\hline Rata-Rata & 134 & 150 & $89 \%$ \\
\hline
\end{tabular}

Berdasarkan analisis perhitungan akhir diperoleh ratarata persentase usability adalah $89 \%$. Jika dikonversikan berdasarkan skala Likert, maka nilai tersebut termasuk kedalam kategori sangat baik. Hasil ini menunjukkan bahwa kualitas perangkat lunak dari aspek usability telah sesuai.

\section{Pembahasan}

Penelitian pengembangan game edukasi "Pengenalan Angka" sebagai media pembelajaran di SLB Arnadya mempunyai tujuan yaitu, 1) mengembangkan media pembelajaran game edukasi berbasis Unity, dan 2) mengetahui kelayakan media pembelajaran berbasis game edukasi sesuai dengan pengujian berdasarkan standar ISO 25010.

Game edukasi pengenalan angka berbasis Unity merupakan media pembelajaran mengenal angka untuk Anak Berkebutuhan Khusus (ABK) golongan Tunagrahita di SLB Arnadya. Game edukasi ini berbasis android agar bisa diakses oleh device yang berbeda. Game edukasi ini dibangun menggunakan software unity. Proses membangun game edukasi ini menggunakan bantuan aplikasi CorelDraw X7 untuk mendesain asset-asset pada game edukasi ini. Hal ini bertujuan untuk memudahkan developer untuk mengembangkan aplikasi.

Pengembangan game edukasi harus memenuhi kriteria kualitas yang baik, oleh karena itu diterapkan pedoman untuk pengembangan aplikasi. Hal ini dimaksudkan agar proses pengembangan aplikasi dapat dipertanggungjawabkan karena telah dilaksanakan berdasarkan prosedur baku yang telah disepakati. Aplikasi ini dikembangkan menggunakan model pengembangan ADDIE. ADDIE secara umum meliputi lima tahap yaitu analisis (analyze), desain (design), pengembangan (development), implementasi (implementation) dan evaluasi (evaluation).

Proses pengembangan game edukasi dimulai dengan tahap analisis kebutuhan sistem. Pada tahap ini dilkaukan melalui pengumpulan data, wawancara dan observasi. Proses wawancara dilakukan kepada Guru wali kelas golongan Tunagrahita. Tahapan ini menghasilkan definisi kebutuhan media yang akan dikembangkan berupa kebutuhan pengguna, analisis kemampuan peserta didik dan tujuan pengembangan dan tujuan pembelajaran untuk menyelaraskan dengan tujuan yang ingin dicapai.

Tahapan selanjutnya adalah tahap desain yang digunakan untuk menghasilkan model produk yang akan dikembangkan. Aplikasi CorelDraw X7 salah satu aplikasi yang paling menunjang pada tahap desain ini, representasi storyboard yang telah dirancang kemudian didesain sehingga menjadi assetasset yang membuat tampilan game edukasi ini menjadi semakin menarik.

Tahapan selanjutnya adalah pengembangan. Pada tahap ini validai dari para ahli yaitu ahli media dan ahli materi menjadi acuan pada tahap revisi produk. Kemudian hasil validasi digunakan untuk merevisi media yang dibuat sehingga menghasilkan media yang layak untuk diujikan.

Tahapan selanjutnya adalah implementasi. Tahapan ini merupakan tahapan untuk uji coba produk yang telah dikembangkan. Uji coba lapangan dilakukan dengan dua tahap yaitu, uji coba kelompok kecil berjumlah 2 orang dan uji coba kelompok besar berjumlah 10 orang oleh peserta didik tunagrahita. Kemudian dilakukan pula pengujian system berdasarkan standar ISO 25010 sebagai uji kelayakan game edukasi yang telah dikembangkan. Pengujian sistem menggunakan 5 aspek saja karena dengan dengan kelima aspek ini sudah cukup untuk menentukan kelayakan game edukasi pengenalan angka ini, 4 aspek tersebut meliputi aspek functional suitability, performance efficency, portability, usability, serta portability \& compability.

Setelah tahap implementasi dilakukan, maka selanjutnya adalah tahap evaluasi. Game edukasi ini direvisi sesuai saran dan masukan ahli media dan ahli materi sehingga menghasilkan produk akhir.

Berdasarkan hasil penelitian pengembangan game edukasi pengenalan angka berbasis Unity untuk Anak Berkebutuhan Khusus (ABK) Tunagrahita di SLB Arnadya setelah divalidasi dan dilakukan pengujian dengan menggunakan standar ISO 25010 dapat disimpulkan bahwa keseluruhan aspek yang diuji telah memenuhi standar kualitas perangkat lunak. Hasil pengujian ini telah merepresentasikan jaminan kualitas produk yang dikembangkan sehigga dapat dinyatakan sistem ini dapat diimplementasikan.

\section{KESIMPULAN}

Berdasarkan hasil penelitian dan pembahasan, berikut ini beberapa simpulan mengenai penelitian "Pengembangan Game Edukasi Pengenalan Angka berbasis Unity untuk Anak Berkebutuhan Khusus (ABK) Tunagrahita di SLB Arnadya";

1. Pengembangan Game Edukasi Pengenalan Angka berbasis Unity untuk Anak Berkebutuhan Khusus (ABK) Tunagrahita dilakukan dengan menggunakan model ADDIE yang terdiri atas 5 langkah yaitu analisis (analyze), desain (design), pengembangan (development), implementasi (implementation) dan evaluasi (evaluation).

2. Hasil pengujian perangkat lunak berdasarkan 4 aspek standar kualitas ISO 25010 diperoleh hasil: a) Aspek functionality berada pada kategori layak; b) Aspek performance efficiency berada pada kategori baik; c) Aspek compability berada pada kategori sangat baik artinya mendukung beberapa device saat menjalankan game dan beberapa aplikasi dan d) Evaluasi sistem oleh pengguna (aspek usability) berada pada kategori sangat baik.

\section{DAFTAR PUSTAKA}

[1] A.S Rosa dan Salahuddin M, 2011. Modul Pembelajaran Rekayasa Perangkat Lunak (Terstruktur dan Berorientasi Objek). Modula, Bandung.

[2] Abdurahman,Maman dan Hayatin Nufus. 2012. Media manik-manik dalam Operasi Penjumlahan bagi SiswaTunagrahita Ringan. Diakses dari www.repository.upi.edu. pada tanggal 2 Juli 2020.

[3] Adi Nugroho. 2010. Rekayasa Perangkat Lunak Berbasis Objek dengan Metode USDP. Penerbit Andi. Jogjakarta.

[4] Ainur, D. 2013. Penggunaan Media Pembelajaran Interaktif Membilang Dan Mengenal Huruf-Huruf Alfabet Untuk Meningkatkan Keaktifan Dan Pemahaman Pada Siswa Tunagrahita Ringan Kelas 1 Sdlb N Cendono Kabupaten Kudus. Skripsi. Diakses dari https://lib.unnes.ac.id/20901/1/5302410065-S.pdf pada tanggal 4 April 2020. 
Jurnal MediaTIK : Jurnal Media Pendidikan Teknik Informatika dan Komputer

[5] Ali Irfan. 2014. Aplikasi Game Edukasi Sebagai Upaya Untuk Meningkatkan Kemampuan Berhitung Pada Anak Berkebutuhan Khusus Tuna Grahita,Surakarta: Universitas Muhammadiyah Surakarta. Diakses dari http://eprints.ums.ac.id/31320/ pada tanggal 4 April 2020

[6] Ardiyanto, S. 2014. Meningkatkan Kemampuan Bina Diri Melalui Analisis Tugas pada Anak Tunagrahita Sedang Kelas 1 di SLB Limas Padang. E-JUPEKhu (Jurnal Ilmiah Pendidikan Khusus), 3(April), 17-37. Diakses dari http://ejournal.unp.ac.id/index.php/jupekhu/article/view/324 5 pada tanggal 4 April 2020

[7] Arief S. Sadiman, dkk. 2009. Media Pendidikan, Pengertian, Pengembangan, dan Pemanfaatannya.Jakarta: Rajawali Press.

[8] Arif Ridwan Rahman \& Dewi Tresnawati. 2016. Pengembangan Game Edukasi Pengenalan Nama Hewan Dan Habitatnya Dalam 3 Bahasa Sebagai Media PembelajaranBerbasis Multimedia. Jurnal Algoritma. Diakses

dari https://jurnal.sttgarut.ac.id/index.php/algoritma/article/view/ $\underline{323 / 300}$ pada tanggal 29 Juni 2020.

[9] Arikunto,S. 2008. Prosedur Penelitian Suatu Pendekatan Praktik. Jakarta: Rineka Karya.

[10] At-Taqwa, Abd. Salam. 2020. Pengembangan Sistem Informasi Bada PelaksanaSains Universitas Negeri Makassar. Skripsi. Makassar: Universitas Negeri Makassar.

[11] Blackman, Sue. 2013. "Unity For Absolute Beginner". New York: Technicat.

[12] Bontos Agus. 2014. Perancangan Game Edukasi Pengenalan Tokoh Pahlawan. Diaksesdarihttps://core.ac.uk/download/pdf/148603953.pdf pada tanggal 4 April 2020

[13] Chu, Phillip. 2009."Learn Unity 4 for IOS Game Development”. New York: Technicat.

[14] Corral, L. R. 2013. A Software Assurance Model for Mobile Applications.Invitation to the Springer Computing Journal.

[15] Costikyan, G. 2013. Uncertainty In Games, The MIT Press, Cambridge.

[16] Cristea, A. 2016. Pengembangan Game Edukasi Menggunakan Unity $3 d$ Berdisiplin Bersepeda Di Jalan Raya Pada Anak Usia 8-11 Tahun. Skripsi. Revista Brasileira de Ergonomia,9(2),10. Diakses dari http://journal.student.uny.ac.id/ojs/index.php/fiptp/article/vi ew/5401/51 06 pada tanggal 29 Juni 2020

[17] David, A. B.2011. Mobile Application Testing (Best Practices to Ensure Quality).Amdocs, Hlm. 2.

[18] Developers. 2014. Dashboards : Platform Version. Retrieved from Android Developers:https://developer.android.com/about/dashboards/ index.html

[19] Drs. Iskani. 2013. Pengukuran Skala Guttman SecaraTradisional.

[20] Emadwiandr. 2019. Hubungan Pengetahuan Orang Tua dengan Kebersihan Rongga Mulut Pada Anak Tunagrahita Di SLB Negeri Ungaran. Hilos Tensados, 1, 1-476. Diakses dari http://repository.unimus.ac.id/1390/ pada tanggal 29 Juni 2020

[21] Fauzia, Khilda. 2012. Peningkatan Keterampilan Membaca Pemahaman Bahasa Jawa Melalui Strategi Direct Reading Thinking Activity Pada Siswa Kelas 5A SDN Tambak Aji 04.Skripsi.Program Sarjana Universitas Negeri Semarang. Semarang.
[22] H, E. D. \&Risal, L., 2011. Pemograman BerorientasiObjek C\# Yang Susah Jadi Mudah. Bandung :Informatika Bandung.

[23] Handriyantini. 2009.Permainan Edukatif Berbasis Komputer Untuk Siswa Sekolah Dasar. Sekolah Tinggi. Malang.

[24] Haryeti, Eli, dkk. 2013. Meningkatkan Keterampilan Membuat Palai Rinuak Melalui Metode Latihan Pada Anak Tunagrahita Ringan. Diakses di http://ejournal.unp.ac.id/index.php/jupekhu/article/download 2097/1767pada tanggal 29 Juni 2020.

[25] Heru Setiawan, dkk. 2013. Analisis Kualitas Sistem Informasi Pantauan Pembentukan Karakter Siswa Di Smk N 2 Depok Sleman. Diakses dari journal.uny.ac.id pada tanggal 1 Maret 2021

[26] Hidayati, H. 2012. Strategi Guru dalam Membelajarkan Matematika pada Anak Tunarungu (Studi Kasus pada Siswa Kelas V SLB-B YRTW Surakarta.Tesis: UNS.Diakses di https://media.neliti.com/media/publications/71534-IDstrategi-guru-dalam-membelajarkan-matema.pdf pada tanggal 29 Juni 2020.

[27] Hobri. 2010. Metodologi Penelitian Pengembangan (Aplikasi pada Penelitian Pendidikan Matematika). Jember :Pena Salsabila

[28] Irsyadi, F. Y. Al, \& Nugroho, Y. S. 2015. Game Edukasi Pengenalan Anggota Tubuh Dan Pengenalan Angka Untuk Anak BerkebutuhanKhusus (ABK) Tunagrahita Berbasis Kinect. Prosiding SNATIF, 2, 1-8. Diakses di http://jurnal.umk.ac.id/index.php/SNA/article/viewFile/296/ 314 pada tanggal 4 April 2020

[29] Ismail, Andang.2009. Education Games menjadi cerdas dan Ceria dengan Permainan Edukatif. Yoyakarta: Pilar Media

[30] Kakojoibari, A.S., Farajollahi, M., Sharifi, A. \&Jarchian, F. 2012. The Effect of Hearing Impairment on Mathematical Skill of Hearing-Impaired Elementary-School Students.Vol 21, No. 2. 19-25.

[31] Kaumar, M., \& Chauhan, M. 2013. Best Practices in Mobile Application Testing. Diakses di Infosys:http://www.infosys.com/flypp/resources/Documents /mobile-application-testing.pdf pada tanggal 8 Maret 2021

[32] M. Ridoi, S.Si, . 2018. Cara Mudah Membuat Game Edukasi Dengan Construct2. Malang: SEAMOLEC.

[33] Mahbubah. 2014. Peranan metode Bermain Sambil Belajar dalam meningkatkan Hasil Belajar Matematika pada Anak Tunagrahita Sedang. 7-24.

[34] Megandari, P. 2016. Strategi Guru Dalam..., Puspita Megandari, FKIP, UMP,2016.

[35] Niknejad, A. 2011. A Quality Evaluation of an Android Smartphone Application.Diakses di https://gupea.ub.gu.se/bitstream/2077/26728/1/gupea_2077 26728 1.pdf pada tanggal 8 Maret 2021

[36] Nunung Apriyanto. 2012. Seluk Beluk Tunagrahita dan Strategi Pembelajarannya.Yogyakarta: Javalitera.

[37] Oliver, J. 2019. Pengaruh Game Edukasi Interaktif Berbelanja Untuk Meningkatkan Kemampuan Mengenal Uang dan Penggunaannya Pada Anak Tunagrahita Ringan Kelas X SMALB di Slb Az-Zakiyah. Hilos T e nsados, 1, 1476. Diakses dari http://repository.upi.edu/2139/ pada tanggal 4 April 2020

[38] Pahruroji, A. 2019. Game bertipe Tower Defense yang memiliki unsur RPG (Journal of Chemical Information and Modeling, 53(9), 1689-1699.

[39] Pratama, U. N., \& Haryanto. 2017. Pengembangan Game Edukasi Berbasis Android Tentang Domain Teknologi Pendidikan. Jurnal Inovasi Teknologi Pendidikan, 4(2) 167- 
Jurnal MediaTIK : Jurnal Media Pendidikan Teknik Informatika dan Komputer

Vol.4 No.3 (September 2021)

$184 . \quad$ Diakses di

https://journal.uny.ac.id/index.php/jitp/article/view/12827/1 0626 pada tanggal 29 Juni 2020.

[40] Pradhan, T.2011. Mobile Application Testing. Diakses di http://www.tcs.com/SiteCollectionDocuments/White $\% 20 \mathrm{~Pa}$ pers/Mobility_Whitepaper_Mobile-ApplicationTesting 1012-1.pdf pada tanggal 8 Maret 2021

[41] Prensky, Marc. 2012. From Digital Natives to Digital Wisdom. New York.

[42] Pressman, R.S. (2010), Software Engineering : a practitioner's approach, McGraw-Hill, New York, 68.

[43] Puspitasari, Y. 2013. Game Edukasi Olahraga Untuk Anak Berkebutuhan Khusus (ABK) Tunagrahita Berbasis Kinect. Diakses pada https://adoc.tips/game-edukasi-olahragauntuk-anak-berkebutuhan- khusus-abk-tun.html pada tanggal 4 April 2020.

[44] Ratno, 2012. Elearning Center. Yogyakarta :s.n.

[45] Rifai, Wafda. 2015. Pengembangan Game Edukasi Lingkungan Berbasis Android. Yogyakarta :Universitas Negeri Yogyakarta. Diaksesdarihttps://eprints.uny.ac.id/21608/1/wafda\%20adita \%20rifai 10520241036. pdf pada tanggal 4 April 2020

[46] Sarwono, Sarlito W. 2017. Psikologi Remaja, Jakarta: PT. Raja Grafindo Persada.

[47] Sudaryono,dkk. 2015. Pengembangan Insrumen Penelitian Pendidikan. Yogyakarta: Graha Ilmu.

[48] Sugiyono. 2017. Metode Penelitian Kuantitatif, Kualitatif, dan R\&D. Bandung :Alfabeta, CV.

[49] S.Wagner. 2013. Software product quality control.pp. 1210.Tersedia: https://www.springer.com/gp/book/9783642385704 pada tanggal 2 Maret 2021.

[50] Usti, Afnita. 2013. Meningkatkan Kemampuan Mengenal Angka Melalui Bermain Pancing Angka Bagi Anak Tunagrahita Ringan. Jurnal Ilmiah Pendidikan Khusus UNP Volume 1 No. 1, Januari 2013. Diakses dari ejournal.unp.ac.id pada tanggal 29 Juni 2020

[51] Wahyu Putra, Dian,dkk. 2016. Game Edukasi Berbasis Android sebagai media pembelajaran anak usia dini. Jurnal $\begin{array}{llllll}\text { Vol. } & 1 & \text { No } & 1 & \text { Maret } & 2016 .\end{array}$ Diaksesdarihttps://ejurnal.unmerpas.ac.id/index.php/informa tika/article/view/7 pada tanggal 29 Juni 2020 